\title{
Feasibility of Developing Butterfly Park as Educational Tourism in Wanagiri Village Forest in Bali
}

\author{
Putu Indah Rahmawati ${ }^{1, *}$ Trianasari Trianasari ${ }^{1}$ I Nengah Suarmanayasa $^{1}$ \\ ${ }^{1}$ Department of Management, Universitas Pendidikan Ganesha, Singaraja, Indonesia \\ *Corresponding author. Email: Indah.rahma@undiksha.ac.id
}

\begin{abstract}
Wanagiri village has a beautiful natural landscape, located above Lake Buyan and Lake Tamblingan, so it is very suitable for selfie tours. In Wanagiri Village there is also a waterfall that has been visited by many tourists. The addition of a butterfly garden in the location around the waterfall will add to the tourist attraction in this area. This study makes a planning design for a butterfly garden and analyzes the business and financial prospects of a butterfly garden in Wanagiri Village. This study used qualitative research methods. Data were taken by observation, documentation and interviews. The researcher collaborates with a team of architects and civil engineering experts to make landscape plans. The study shows the prospects of the butterfly garden as a business center to be developed in Wanagiri Village. The development of a butterfly garden in Wanagiri Village will increase the welfare of the community.
\end{abstract}

Keywords: Planning, Butterfly Park, Tourism Village, Educational Tourism, Business Feasibility, Village Forest.

\section{INTRODUCTION}

Wanagiri Village is a beautiful tourist village in Bali. This village is located at the entrance to the north of Bali. Its position is very strategic because it is located in the middle so that it is easily accessible by tourists from southern Bali and tourists from northern Bali. Wanagiri village already has a name that is quite famous for tourists, namely with its natural beauty. The natural beauty of Lake Tamblingan and Lake Buyan looks very charming when viewed from Wanagiri Village and then packaged into a selfie tourist spot by Pokdarwis Wanagiri. In normal situations before the COVID-19 pandemic, many tourists came and took the time to take photos at the selfie location in Wanagiri Village.

In addition, the forest of Wanagiri Village itself represents a mountain forest topology with various conditions. The main tourism utilization potential found in this village forest is a waterfall (See Figure 1). There are more than a few waterfalls scattered in the Wanagiri Village Forest area, but only a few have been developed for nature tourism. In normal situations before the COVID-19 pandemic, the waterfall in Wanagiri Village was very crowded with local and foreign tourists. In a day there are about 100 tourists who come to Banyumala Waterfall.
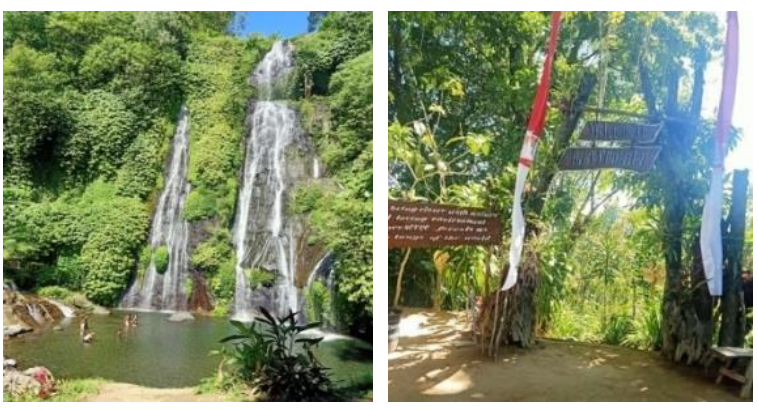

Figure 1. Wanarigi Waterfall

Selfie tourism is the main attraction of Wanagiri Village [1] Wanagiri Tourism Village also still has a lot of tourism potential that has not been explored to be able to have an economic impact on the local community, such as agro tourism, cycling tourism, spiritual tourism and educational tourism [2]. These various tourism potentials require a special touch both in terms of packaging tourism products and from marketing. This research is a follow-up study from the previous year. [2] Found that there are several tourism potentials that need to be studied to be developed in Wanagiri Village to be a source of income for the community. One of the potentials that might be developed is a butterfly garden which can be an interesting family education tour. The development of the butterfly garden is in accordance with the conditions of the forest land which is already planted with many flowers by the local community. So that the arrangement does not conflict with the principles of sustainable forest management. This study aims to plan the development of a butterfly garden in the Wanagiri. 
Village Forest in terms of landscaping and also to analyze its business and financial prospects for the welfare of the community.

\section{LITERATURE REVIEW}

\subsection{Forest-Based Tourism}

Law of the Republic of Indonesia Number 41 of 1999 concerning Forestry Article 1 paragraph 2 that forest is an ecosystem unit in the form of a stretch of land containing biological natural resources which is dominated by trees in a natural environment that cannot be separated from one another. The condition of forests, especially in conservation areas, is unique both in terms of landscape and biodiversity. Communities around the forest have sufficient access to interact with the forest and are placed in an equal position with other stakeholders in the implementation of forest resource management [3].

Nature conservation has been an issue in tourism sector, especially to those outdoor activities tourism, such as leisure walks in the wild/hiking, hiking/trekking or mountain biking. Although beneficial for humans, on the other hand this activity can have an ecological impact on forest ecosystems[4]. There have been many studies related to the economic value of forest use for tourism activities [5][6][7][8]. [5] stated that in Germany, the use of forest as tourism has gained more than $\$ 2$ billion/year. The forest tourism has also been beneficial for the surrounding; improving the business of the local communities. [6]. Similarly, [7] found that in Ecuadorian Amazon, the local communities gains various benefit from the use of forest as tourism site, which eventually become local income. Development of tourism in National Parks in Sweden has also show the positive result; employment of the local in the restaurant and accommodation sector [9]. Tourism in the forest has gained multiplier-effect to the local inhabitants; through employment and socio-economic values [10].

Forest tourism is an important form of educational tourism [11]. The educational purposes of educating natural ecosystem, diversification, and conservation can be gained through forest tourism [11]. Through education and tourism, the efforts in conserving ecosystems of the forests can be maintained [12]. Moreover, local inhabitants' awareness of the importance of forest can be obtained through tourism and education. [12]. The value of socio-economic gained by the torusim activities in the forests could increase awereness. As an example, the tourism activity in Monkey Forest in Ubud has developed local inhabitants' awereness to preserve the nature [13].

Forest-based Tourism can also be interpreted as Forest Area Ecotourism. [14] states that ecotourism has 3 dimensions, namely:

1) Conservation, which means that tourism activities help local nature conservation efforts with minimal negative impacts.
2) Education, tourists who take the tour will gain knowledge about the uniqueness of biology, ecosystems and social life in the area visited.

3) Social, namely the community has the opportunity to carry out social activities in the area.

According to The Ecotourism Society [15], there are eight principles in ecotourism activities, namely: (1) Preventing and overcoming tourist activities that interfere with local habits and nature, (2) education of conservation, (3) Income directly for the area, (4) community-based participation, (5) income generator for inhabitants, (6) harmonizing nature and inhabitants, (7) maintaining environmental carrying-capacity and (8) increasing foreign exchange for the government.

\subsection{Tourism Village Area Development Concept}

In compiling the concept of developing a tourist village area, there are spatial and non-spatial concepts. The spatial development of tourist village areas includes:

1) Developing tourism route.

2) Availability of special means of transportation to tourism objects

3) Convenience infrastructure, including road.

4) Availability of tourism facilities

5) Provision of lodging facilities

6) Availability of unique local handicraft.

7) Availability of decent and unique restaurant with village characteristics.

Non-spatial development according to [16] are: (1) making regulations for tourists who visit and carry out tourism activities; (2) developing an agro-tourism-based village completed with attractions; (3) enhancing HRD through educational efforts (training); (4) supporting the tourism with excellent marketing strategy; (5) developing regulations or policies to support the process.

\subsection{Review of Previous Research}

Research in the field of tourism destination planning has been widely carried out in Indonesia and abroad. Some examples of previous research include: (1) Research on the strategy of developing the Mount Galunggung tourism area by Mukhsin (2014) which uses qualitative analysis to prepare development plans in the Mount Galungung tourist area; (2) Development of Situ Sanghyang Tourism Potential in Tanjungjaya District, Tasikmalaya Regency by [17]; Research related to the study of potential and strategies for developing ecotourism in the Sempu Island nature reserve, Malang district, East Java province [18]. The three studies have in common, namely using qualitative analysis by using 
local tourism stakeholders to find research data. However, similar research has never been carried out in Bali, especially regarding the master plan and governance of tourist destinations. Therefore, this study tries to fill the knowledge gap by using Wanagiri Village as the research location.

The research of [19] confirms that in planning the development of tourist destinations, the active participation of the community is very necessary. It is further suggested that planning be organized and systematic in accordance with the socio-economic impacts that may be generated from tourism activities in a destination. Based on the results of research in the [20]concluded that the success factors of communitybased tourism in the development of tourist villages are: (1) the uniqueness of the location is the main attraction that causes tourism activities.

The uniqueness of this location can be in the form of natural, historical and cultural physical attractions; (2) community involvement as the main tourism actors; (3) fund facilitation based on the embryo of tourism actors;(4) the driving figures are people who have a big role in moving the wider community to get involved in the tourism business. This driving figure must be able to lead (leadership); (5) link is a partnership relationship that exists with important stakeholders who have a role in the development of tourist villages, for example partnerships with the central government, regional governments and local entrepreneurs.

\section{METHOD}

\subsection{Research sites}

The research will be conducted in Wanagiri Tourism Village in Buleleng Regency, Bali Province. The map of the research location can be seen in Figure 2 .

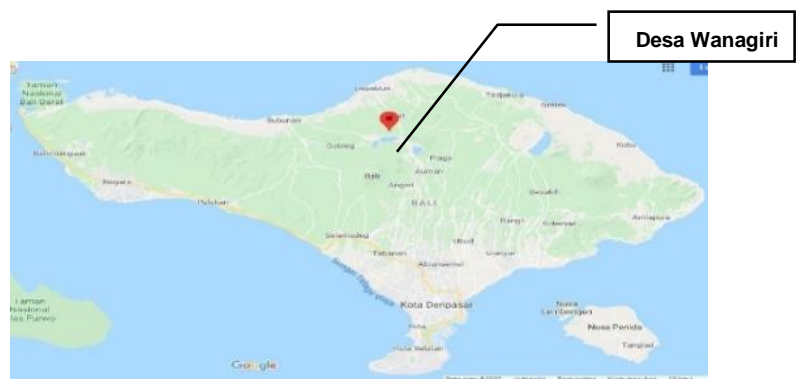

Figure 2. Bali Map

\subsection{Data Collection Techniques}

The techniques used to collect data in this study are:

(1) Interview

It is very important to collect data through interviews to get empirical and direct data from respondents who understand the research context. In accordance with the opinion of experts, the interview technique is used in this study because: (1) it allows researchers to collect rich and dense empirical data about the topic being studied [21]; (2) can ensure its validity and accuracy [22]; and (3) interviews allow researchers to observe the surrounding environment, ask longer questions and achieve high response rates compared to survey methods [23]. Researchers used structured questions and recording aids to assist in conducting interviews.

\section{(2) Observation}

Observations were made to enrich the research results and to adjust the planning to the real conditions in the field.

\section{(3) Documentation}

Photo documentation were taken to provide the original views of forest before and after the planning. We conducted topography data collection to ensure that the planning suitable with the land contour.

\section{(4) Focus Group Discussion}

Focus group discussion was conducted to ensure the community involved in the planning and to get the community point of view regarding the planning.

\subsection{Data Analysis}

The data collected in this study will be analyzed using qualitative data analysis techniques. In thematic analysis, the similar themes will be gathered and analyzed and categorized. [24]. [25] states that the process of analyzing qualitative data was following several steps, including note taking and reading, listening and transcribing, as well as synthesizing data through sorting and organizing. In other words, [26] state that analyzing qualitative data involves three steps: (1) data reduction, meaning that researchers organize data into clear patterns; (2) data display, namely analyzing qualitative data in a way that can be understood and evaluated by the reader; (3) drawing conclusion and verification.

\section{RESULTS \& DISCUSSION}

The land used for tourism and creative economic activities is the forest area of Wanagiri Village, which naturally has beautiful land contours and configurations. In the spatial arrangement, it does not change the function and designation of the existing space too much. For example, land that is usually only forest and not used in any activities will slightly change its appearance to become a camping ground. So that tourists stay in the forest without destroying the forest land itself. Large trees are created into wooden houses that will add to the value of the forest land into land that is of interest to tourists aged children and teenagers. Another example is the flower garden area which was then architecturally given an artistic touch to become an orchid garden and a butterfly garden. So, the function of the land from a 
thousand flower gardens to become an orchid garden or an orchid garden will not damage the sustainability of the forest. The difference that occurs is that if the flower forest breaks a thousand, the flowers are sold to make money. However, if you have an orchid garden, the flowers remain in the forest and you cannot pick them, but more money will come. So, it is economically and ecologically more profitable. Likewise with the butterfly garden, it is more profitable than an ordinary village forest which only relies on selling thousand broken flowers at a price of Rp. 5,000/stem. With the butterfly garden, the forest with beautiful flowers is maintained without damaging the flower trees and earns up to Rp. $30,000 /$ person. The economic potential is far more profitable than just a thousand flower gardens.

\subsection{Previous Location}

Creative Economy businesses that already exist in Wanagiri Village (for example: selfie tours for photography businesses, culinary businesses, tourism businesses, forest product processing businesses and crafts) will be added with several new facilities and facilities that will be able to boost the productivity and profitability of existing businesses. In this Wana Kreatif proposal, several facilities were added, including: a butterfly garden. The following is a design plan for the Wanagiri Village Butterfly Garden (Figure 3-5).

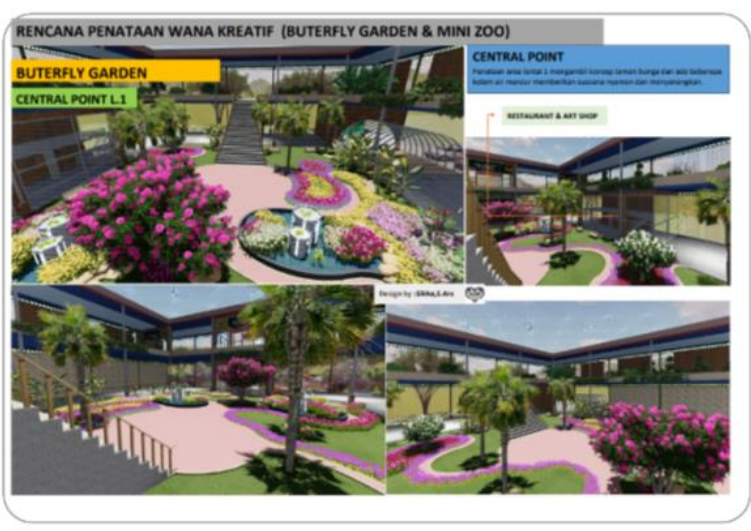

Figure 3. Butterfly Garden Seen from Entrance Gate
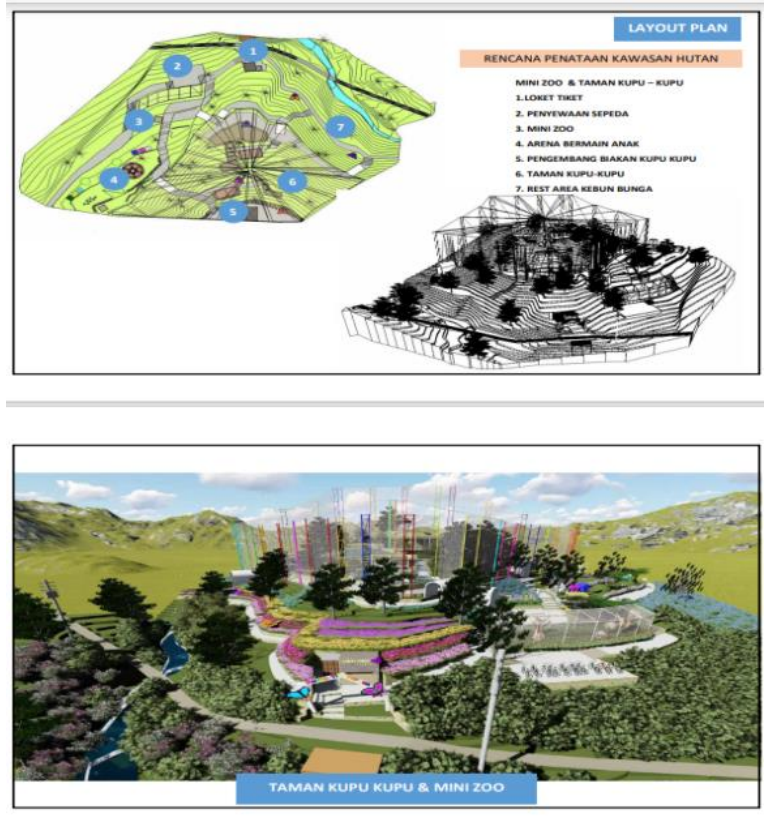

Figure 4. Butterfly Park Master Plan Seen From Above

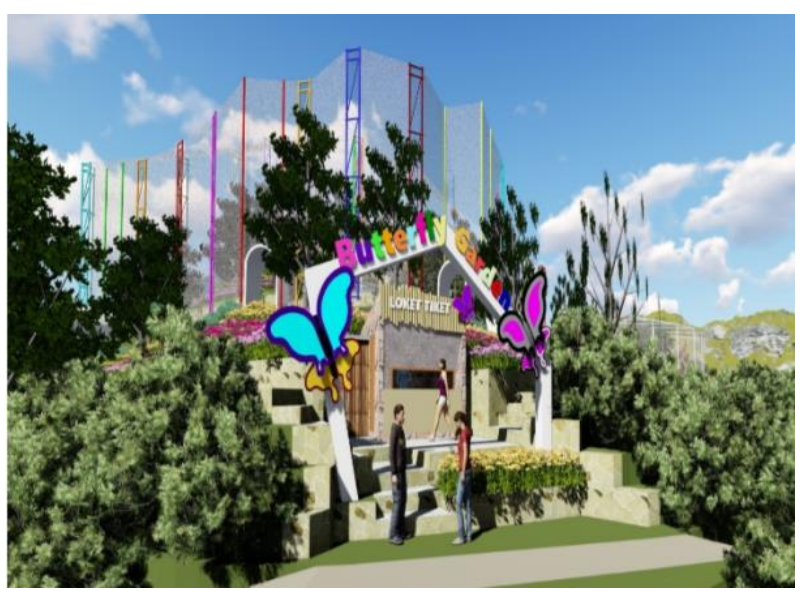

Figure 5. Butterfly Garden Seen from a Front Side

\subsection{Feasibility Study of Butterfly Garden Business}

This feasibility study provides a technical, economic and financial justification of a decision to finance an investment project. The feasibility study analyzes the level of the future investment objective, considering factors of risk and uncertainty in order to calculate the viability of the future project investment. Table 1 and 2 are the calculation of Butterfly Park at Wanagiri Village. 
Table 1. Wanagiri Village Butterfly Park Revenue Projection

\begin{tabular}{|c|c|c|c|c|c|}
\hline \multirow[b]{2}{*}{ FIRST YEAR INCOME } & \multirow{2}{*}{$\begin{array}{l}\text { Number Of } \\
\text { Tourists/ } \\
\text { Day }\end{array}$} & \multirow{2}{*}{$\begin{array}{l}\text { Number Of } \\
\text { Tourists/ Year }\end{array}$} & Adult Ticket & Children Ticket & Foreign Tourists \\
\hline & & & IDR 25.000 & IDR 10.000 & IDR 50.000 \\
\hline $\begin{array}{l}\text { Waterfall entrance ticket } \\
\text { sales }\end{array}$ & 30 & 10950 & IDR $273,750,000$ & IDR $109,500,000$ & IDR $547,500,000$ \\
\hline $\begin{array}{l}\text { Mini zoo entrance ticket } \\
\text { sale }\end{array}$ & 30 & 10950 & IDR $273,750,000$ & IDR 109,500,000 & IDR $547,500,000$ \\
\hline $\begin{array}{l}\text { Butterfly garden ticket } \\
\text { sale }\end{array}$ & 30 & 10950 & IDR $273,750,000$ & IDR $109,500,000$ & IDR $547,500,000$ \\
\hline selfie travel sales & 30 & 10950 & IDR $273,750,000$ & IDR 109,500,000 & IDR $547,500,000$ \\
\hline food sales & 30 & 10950 & IDR 273,750,000 & IDR 109,500,000 & IDR 547,500,000 \\
\hline Beverage sales & 30 & 10950 & IDR 273,750,000 & IDR 109,500,000 & IDR 547,500,000 \\
\hline Souvenir sales & 30 & 10950 & IDR $273,750,000$ & IDR 109,500,000 & IDR $547,500,000$ \\
\hline Snack sales & 30 & 10950 & IDR $273,750,000$ & IDR 109,500,000 & IDR $547,500,000$ \\
\hline Total revenue per market & & & IDR 2,190,000,000 & IDR $876,000,000$ & IDR 4,380,000,000 \\
\hline TOTAL REVENUE & & & & & IDR $7,446,000,000$ \\
\hline
\end{tabular}

Table 2. Profit Target

\begin{tabular}{|c|c|c|}
\hline EXPENDITURE & $\begin{array}{c}\text { Percentage } \\
(\%)\end{array}$ & Nominal \\
\hline Employees salary & $35 \%$ & IDR $2,606,100,000$ \\
\hline Water & $5 \%$ & IDR $\quad 372,300,000$ \\
\hline Electricity & $5 \%$ & IDR $\quad 372,300,000$ \\
\hline Administration & $5 \%$ & $372,300,000$ \\
\hline Maintenance & $15 \%$ & IDR $1,116,900,000$ \\
\hline $\begin{array}{ll}\text { Research anc } \\
\text { Development }\end{array}$ & $5 \%$ & $372,300,000$ \\
\hline TAX & $10 \%$ & $744,600,000$ \\
\hline $\begin{array}{l}\text { TOTAL } \\
\text { EXPENDITURE } \\
\text { PER YEAR }\end{array}$ & $75 \%$ & IDR 5,956,800,000 \\
\hline PROFIT TARGET & $20 \%$ & IDR $1,489,200,000$ \\
\hline
\end{tabular}

In Table 2, it can be seen that the Butterfly Park in Wanagiri Village has the potential to provide economic benefits to the community and to the government in the form of taxes that can be generated every year. Taxes that can afford will be deposited to the government of IDR 900 million per year so it can be said that the Pay Back Period to the government is 3.5 years. The tax that will be deposited back to the government still continues every year. While the economic benefits in the form of employee salaries every year is Rp. 3.2 billion per year and this value will give a multiplier effect to other economic sectors because there is an increase in people's purchasing power. Furthermore, managers still have profits that can be used for development and other more prospective innovations in the future.

\section{CONCLUSION}

Village has the opportunity to be developed as an educational tour. The addition of a butterfly garden will add to the value of the existing tourist attraction in Wanagiri Village. This will increase income and improve the welfare of the village community. This feasibility of the Butterfly Park business will be submitted to a start-up program or a matching fund program to get funding assistance from government or any other funding sources.

\section{REFERENCES}

[1] S. Widyastuti, N. K., Luh, N., Prawitha, C., \& Suyasa, "Wisata Swafoto Sebagai Daya Tarik Wisata," Sintesa, no. https://jurnal.undhirabali.ac.id/index.php/sintesa/art icle/view/504, pp. 363-370, 2018.

[2] K. Rahmawati, P. I., Andiani, N. D., \& Agustini, "Pelatihan Tata Kelola Desa Wisata Wanagiri Berbasis Teknologi Informasi,” pp. 229-234, 2020.

[3] S. Rianto, "Good Forest Governance Sebagai Syarat Pengelolaan Hutan Lestari: Permasalahan 
Kelembagaan Masyarakat Dalam Tata Kelola Kehutanan Di Jawa Tengah,” p. 27.

[4] Rosalino, L. M. and Grilo, and Clara, "What drives visitors to Protected Areas in Portugal: accessibilities, human pressure or natural resources?," J. Tour. Sustain., vol. 1, pp. 3-11, 2011.

[5] P. Elsasser, "Recreational benefits of forest in Germany. In: Roper, C \& Park, A . (eds). The living forest: The non-market benefits of forestry," Station. Off. London, pp. 175-188.

[6] K. Lindberg and J. Enríquez, An analysis of ecotourism economic contribution to conservation in Belize, volume 2: Comprehensive report. World Wildlife Fund and Ministry of Tourism and the Environment (Belize), Washington, DC. 1994.

[7] S. Wunder, "Promoting forest conservation through ecotourism income: A case study from Equadorian Amazon Region. Conference International for Forestry Research. Occasional," 1999.

[8] E. A. Ellis and L. Porter-Bolland, "Is communitybased forest management more effective than protected areas?. A comparison of land use/land cover change in two neighboring study areas of the Central Yucatan Peninsula, Mexico," For. Ecol. Manage., vol. 256, no. https://doi.org/10.1016/j.foreco.2008.07.036, pp. 1971-1983, 2008.

[9] Lundmark, P. L. J. T., Fredman, and K. Sandell, "National parks and protected areas and the role for employment in tourism and forest sectors: A swedish case. Ecology and Society," Ecol. Soc., vol. 15, no. 1, 2010.

[10] S. K. and R. R. Jacobson, "Ecotourism, Sustainable Development, and Conservation Education: Development of a Tour Guide Training Program in Tortuguero, Costa Rica," Environ. Manage., vol. 16, no. 6, pp. 701-713, 1992.

[11] Bhuiyan, M. A. H. R. Islam, and Chamhuri Siwar Shaharuddin Mohamad Ismail, "Educational Tourism and Forest Conservation: Diversification for Child Education," Procedia - Soc. Behav. Sci., vol. 7, pp. 19-23, 2010.

[12] M. Alam, Y. Furukawa, and S. Akter, "Forest basedtourism in Bangladesh: Status, Problems, and Prospects. Tourismos: An International Multidisciplinary," J. Tour., vol. 5, no. 1, pp. 163172, 2010.

[13] B. P. Wheatley and D. K. Harya Putra, ."The effects of tourism on conservation at the monkey forest in Ubud, Bali, Société nationale de protection de la nature et d'acclimatation de France, Paris (FRA)," 1994.

[14] F. Kesuma, "Potensi Pengembangan Ekowisata di Wilayah Pesisir Pulau Talise Sulawesi Utara.," Institut Pertanian Bogor. Bogor., 2000.

[15] M. Fandeli C, Pengusahaan Ekowisata. Yogyakarta: Fakultas Kehutanan Universitas Gadjah Mada., 2000.

[16] F. Zakaria and Suprihardjo, "Konsep Pengembangan Kawasan Desa Wisata di Desa Bandungan Kecamatan Pakong Kabupaten Pamekasan," Tek. Pomits, vol. 3, no. 2, pp. C245C249, 2014, [Online]. Available: https://doi.org/2337-3520.

[17] N. Hendriawan, "Pengembangan Potensi Situ Sanghyang di Kecamatan Tanjungjawa Kabupaten Tasikmalaya. Pengelolaan Sumberdaya Wilayah Berkelanjutan," vol. 1, pp. 417-430, 2017.

[18] T. Muttaqin, R. H. Purwanto, and S. N. Rufiqo, "Kajian Potensi dan Strategi Pengembangan Ekowisata Di Cagar Alam Pulau Sempu Kabupaten Malang Provinsi Jawa Timur," J. GAMMA, vol. 6, no. 2, pp. 152-161, 2011.

[19] E. Kurniawati, D. Hamid, and L. Hakim, "Peran Masyarakat Dalam Perencanaan Dan Pengembangan Desa Wisata Tulungrejo Kecamatan Bumiaji Kota Batu,” J. Adm. Bisnis, vol. 54, no. 1, pp. 8-14, 2018.

[20] H. P. J. Putri and A. Manaf, "Faktor Â Faktor Keberhasilan Pengembangan Desa Wisata Di Dataran Tinggi Dieng," Tek. Perenc. Wil. Kota, vol. 2, no. 3, pp. 559-568, 2013.

[21] G. Jennings, “Tourism research. Milton, Qld: John Wiley \& Sons.," 2010.

[22] L. Dwyer, A. Gill, and N. Seetaram, "Handbook of research methods in tourism: Quantitative and qualitative approaches. North hampton: Edward Elgar Pub.," 2012.

[23] W. . Neuman, "Social Research Methods: Qualitative and Quantitative Approaches. 7th Edition, Pearson, Boston.," 2011.

[24] H. Fussel, “A Generally Applicable Conceptual Framework for Climate Change Research. Global Environmental Change," 2007, vol. 17, no. 2, pp. 155-167.

[25] A. Veal, Research Methods for Leisure and Tourism: A Practical Guide, 3rd edition, Harlow, UK: Pearson. 2006.

[26] D. Crowther and G. Lancaster, Research Methods A concise Introduction to Research in Management and Business Consultancy. 2012. 